\title{
The quality of audit recommendation: The effect of role conflict, role ambiguity and work stress
}

\author{
Meinarni Asnawi ${ }^{\text {* }}$
}

${ }^{\mathrm{a} L e c t u r e r, \text { Department Accounting-Universitas, Cenderawasih Papua, Indonesia }}$

\begin{tabular}{l}
\hline C H R O N I C L E \\
\hline Article history: \\
Received August 25, 2021 \\
Received in revised format \\
September 282021 \\
Accepted November 102021 \\
Available online \\
November 102021 \\
\hline Keywords: \\
Role conflict \\
Role Ambiguity \\
Work stress \\
Quality of audit recommendations
\end{tabular}

\section{Introduction}

The role of internal auditors is getting attention as a form of internal control to reduce fraud and increase transparency and accountability in financial management, (Jachi \& Yona, 2019; Neu, Everett, \& Rahaman, 2013; Roussy \& Brivot, 2016; Roussy M., 2015; Sukirman \& Sari, 2013; The Institute of Internal Auditors., 2019). Several previous studies have linked the role of internal auditors with role ambiguity and role conflict that have an impact on auditor work stress (Fisher, 2001; Ram et al., 2011; Ahmad \& Taylor, 2009; Larson, 2004; Fisher. \& Gitelson, 1983; Baths, 1980; Jackson, 1985; Soltania et al., 2013). Various prior studies have linked the role of internal control to audit quality (Al-Khaddash et al., 2013; Hafizuddin Islami \& Sukarmanto, 2020; Bahtiar, 2019; Ahmad. \& Taylor, 2009; Fisher, 2001; Koo \& Sim, 1999; Hameed, 1995). Previous research has proven the influence between these variables, for examples, the role of internal auditors in private organizations, such as companies (Ram et al., 2011; Soltani et al., 2013; Shbail, 2018), and public organizations such as hospitals and governments (Hoseini et al., 2021; Phillips \& Andrews., 2014), (Fang \& Baba, 1993) (Ratmono \& Darsono, 2022), However, the role of internal auditors associated with role ambiguity and role conflict at universities still needs to be undertaken since the universities have different operational rules. For example, potential conflicts may appear as the auditors face clients who turn to be their colleagues or friends. These auditors could also experience work stress as a result of their additional work besides teaching and research duties as individual lecturers. This influences their performance and quality of audit recommendation (Fisher, 1995; Ram et al., 2011; Bahtiar, 2019).

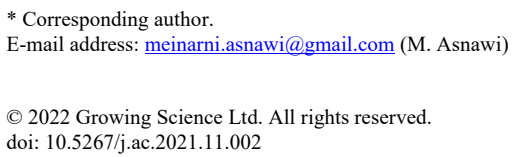


Internal auditors in universities have the potential to experience role stress (ambiguity and conflict) because they have dual roles as internal auditors and as lecturers. It is not easy for them as internal auditors in carrying out their internal control duties because the work environment allows them to meet with colleagues or leaders, and this can trigger role conflicts. This condition can trigger a role conflict, which is a situation where the internal auditor/lecturer has more than one role in the work environment where the goals of his work may conflict with one another, (Ahmad. \& Taylor, 2009; Al-Khaddash et al., 2013; Ariati, 2014; Fisher, 2001; Fisher \& Gitelson, 1983). This subsequently can lead to work stress due to the increase in workload from multiple roles (Grzywacz, 2006; Matthews, 2010; Soltania et al., 2013). This relationship causes internal auditors to have inherent conflicts with themselves (inherent conflict). The inherent conflict with the duties and responsibilities of supervisors (internal auditors) is difficult to maintain between work professionalism and institutional/ organizational commitment and those involved in it. Work discomfort conditions can have a negative impact on individual behavior such as the emergence of work tension, the number of transfers, a decrease in job satisfaction so that it can reduce the overall performance of the auditor (Fanani et al., 2008). This study examines the effect of role conflict and role ambiguity on quality of audit recommendation considering work stress variables. examines the effect of role conflict and role ambiguity in the quality of audit recommendations considering the important role of work stress. Previous studies have confirmed the relationship between these variables, but the main question and challenge is the type and direction of the relationship between these variables in the special case of internal auditors in an educational institution. Therefore, this study fills the gap by determining the type and direction of the relationship to determine the type and direction of the relationship between role conflict, role ambiguity, work stress, and quality of Audit Recommendations.

\subsection{Literature Review and Hypothesis}

\section{Role Theory}

The role is something that is experienced or lived by someone in their activities, which can vary from one time to another in an organization. The roles of each individual are interdependent, structured, organized and create a network of tasks and responsibilities (Dukerich \& Ashforth, 2001; Biddle, 1986; Katz \& Kahn, 1987). Stryker and Burke (2000) argue that roles can be linked to how work is designed, communicated, accomplished, evaluated, and experienced (Welbourne et al., 1998). Role stress can occur because individuals play more than one role so that it affects the welfare of workers and organizational functions that occur in the work environment. Role stress consists of role ambiguity and role conflict (Katz \& Kahn, 1978), namely the experience of individuals receiving incompatible or conflicting requests (role conflict) and/or lack of sufficient information to carry out their work. Role conflict occurs when incompatible demands are placed on a person related to their job or position. Katz and Kahn (1978) found that people experience role conflict when they find themselves capable of responding to or doing the status/job for which they are responsible while Gerber and Macionis (2010) state that role conflict can be something that can occur for a short time, or for a long period of time, and can be related to one's situational experiences. Role conflict begins with a person's desire to achieve success, and the pressure placed on the two demands that must be successful from work are incompatible with each other. The effects of role conflict, discovered through case studies and national surveys, relate to individual personality characteristics and interpersonal relationships. Kahn et al. (2010) concluded that individual personality characteristic conflicts can arise in conflict personality roles where aspects of one's personality conflict with other aspects of the same individual's personality. Interpersonal relationships can cause conflict because they mean the relationship between two or more people who have a relationship, at first glance, it can last but the rest can cause conflict (Truett., 1979). Role strain or "role pressure" may arise when there is a conflict in the demands of roles, when an individual does not agree with the assessment of others concerning his or her performance in his or her role, or from accepting roles that are beyond an individual's capacity. Internal auditors in universities in Indonesia have two different roles, namely as a managerial consultant and monitoring in addition to their main role as a lecturer. Internal Auditors in Higher Education strive to meet the demands of two or more roles at the same time, resulting in role conflicts and having consequences for their performance (Fanani et al., 2008). Flahrety and Dahlstrom (1999) found that role conflict was negatively associated with increased job performance. This shows that the higher the role stress, the lower the job performance. Role conflict is said to exist when there are important differences among the ratings given for various expectations. By comparing the extent of agreement or disagreement among the ranks, a measure of role conflict was obtained (Gerald, 2011).

\subsection{Effect of Role Conflict and Role Ambiguity on the Quality of Audit Recommendation}

Rizzo et al. (1970) stated that role ambiguity indicates ambivalence when what is expected is unclear due to a lack of information about a role and what is required in a task. Ahmad and Taylor (2009) found that ambiguity and role conflict affect independent commitment. Fisher (1995) found that role ambiguity and conflict have a negative effect on job performance. Yung-Tai and Chen-Hua (2010) found that there is a negative effect between role ambiguity and employee creativity while role conflict has a positive effect on creativity. Fanani et al. (2008) provide evidence that role ambiguity has no effect on performance, whereas Robkob et al. (2012) and Baotha and Ussahawanitchakit (2009) found that auditor independence has a significant effect on auditor performance, the same research results are obtained from research. Research in Indonesia conducted by Widianingsih (2016) found that there was an influence of the professionalism of the Internal Auditor and the role stress of the Internal Auditor on the quality of internal audit recommendations. Analyzing the influence 
of the internal auditor's role stress on the quality of the internal auditor's recommendations found that role conflict and ambiguity conflict affect the quality of internal audit recommendations (Herlinawati, 2012)

$\mathbf{H}_{1}:$ There is an effect of role conflict on the quality of audit recommendations.

$\mathbf{H}_{2}$ : There is an effect of role ambiguity on the quality of audit recommendations.

\subsection{The effects of role of conflict and role ambiguity on the work stress}

Cooper and Robertson (1998) expressed that discomfort over role conflict and role ambiguity can result in an uncomfortable workplace. (Schuler, 1980) defines stress as a dynamic condition in which a person is faced with an opportunity, constraint, or demand related to what they want, and the outcome is perceived to be uncertain and important. Every position in an organization has role conflict and role ambiguity. Deviant behavior and violations of the code of ethics can still be carried out by internal auditors considering that internal auditors have an important role in the organization. The role of internal auditors at universities is an important part of a supervisory institution which is expected to be a catalyst in the process of financial management transparency towards good university governance (Sukirman \& Sari, 2013). Auditors can be confronted by the dualism of assignments or orders and must be able to choose one of them without leaving the impression of dereliction of duty. Role conflict and role ambiguity are among the antecedents of work stress which have been most cited in the research literature (Fisher \& Gitelson, 1983). Role conflict, that is pressure to perform in two or more incompatible ways, has been tied conclusively to occupational stress in Various Western research (Fang \& Baba, 1993), (Fisher \& Gitelson, A meta-analysis of role conflict and ambiguity., 1983). Workplace conflict occurs due to excessive working time. The conflict is caused by tension and is more based on behavior. (Jerusalem \& Chen, 2009). Tension-based conflict is a conflict caused by physical fatigue, depression, and irritability (Greenhouses \& Beutell, 1985; Xu, 2009), whereas behavior-based conflict is a conflict caused by individual with the behavioral expectation plays two different incompatible roles, such as the role of a father in his family as well as auditor (Greenhouses et al., 1989; Xu, 2009). Work stress consists of organizational stress and managerial stress. Managerial stress consists of role ambiguity, role conflict, workload pressure, quality pressure, job sensitivity, while organizational stress consists of development and promotion, accountability for employee performance, time pressure, and work-related technology (Ivancevich, 2007). Job conflict is caused by each individual or worker playing more than one role, thus triggering tension due to competition between workers, power struggles, ego, pride, jealousy due to differences in performance, compensation problems, etc. Myaat (2012) explained that there are two main triggers at the root of conflict, namely poor communication and the inability to control emotions, whereas Robkob et al. (2012) and Baotha and Ussahawanitchakit (2009) found that auditor independence has a significant effect on auditor performance.

$\mathbf{H}_{3}:$ There is an effect of role conflict on work stress.
$\mathbf{H}_{4}:$ There is an effect of role ambiguity on work stress.

\subsection{The effect of work stress on quality of audit recommendation}

Work stress is experienced as a harmful reaction to undue pressures and demands at work (Bhui et al., 2016). Winoto and Harindahyani (2020) conclude that auditor's work stress affects audit quality significantly but negatively and Dashti and Saedi (2020) found that stress, social pressure, and time pressure reduced audit quality significantly. Zadegan and Aqa'i (2018) tested companies in Tehran Stock Exchange and concluded that auditor's stress contributed to a sharp drop in audit quality. Lu et al. (2010) stated that individual responses to work stress could affect physical and mental health, work quality, and even organizational performance through the stimulus and response system. Workplace stress arises when employees detect workplace demands for adaptation and adjustment beyond their capabilities and resources. Some research on job stress has concentrated on aspects of the workplace, which can cause employees to become depressed. Conflicts can occur in the workplace and then continue at the home (when work is brought home) and conversely, conflicts at home can carry over to the workplace (when family conflicts are carried over to the workplace) (Eby et al., 2005; Soltania et al., 2013). Huanmin Yan and Xie (2016) stated there is a significant negative association between work stress and audit quality in the initial audits of new clients. Combining various interpretations of work stress, we define it as a series of physiological, psychological, and behavioral responses due to the continuing effects of one or more stressors on individuals in an organization (Xu, 1999). In terms of auditing, auditors' work stress mainly results from the conflict between limited auditing resources and overwhelming audit workload within a limited time window (Lo' pez \& Peters, 2012).

\section{H5: Work stress affects the quality of audit recommendations.}

\section{Research method}

The sample in this study was the internal auditors at several Universities in Indonesia with a total of 96 respondents selected using the snowball sampling method approached to fill in an Online questionnaire. Respondents include $64 \%$ female and the rest $34.4 \%$ male participants with the average experiences around 4.24 years whilst $87 \%$ have $\mathrm{PhD}$. The sampling method uses the GPower test 3.12 with the calculation result of the minimum number of samples being 89 respondents. The number of respondents in this study was 96 respondents and had met the sample eligibility criteria. The role stress instrument 
(role conflict and role ambiguity) was developed from the instrument (Rizzo et al., 1970). Work stress instrument was modified from The Brief Job Stress Questionnaire (Johas, 2020) and the Internal Audit Quality Recommendation Instrument was developed from the MENPAN Regulation and the Republic of Indonesia Supreme Audit Agency Regulation concerning State Financial Audit Standards (SPKN) in appendix 3 paragraph 17 that all instruments have been adjusted to the internal audit conditions of Universities in Indonesia. There 34 questions are asked using a Likert scale of 1-5 whilst the data are analyzed using SmartPLS.

\section{Result and Discussion}

In the analysis of SmartPLS, the first step is to assess the measurement model (outer model). The outer model comprises the component of the measurement, which determines how well the indicators (items) theoretically load and connect with the corresponding constructs. Table 1 presents the factor loadings for the items and the significance level of factor loadings respectively. These items were then used for further analysis in SmartPLS.

Table 1

Average value and outer loading every indicator

\begin{tabular}{|c|c|c|c|c|}
\hline Construct & Items & Loading & Mean & P-value \\
\hline \multirow{5}{*}{$\begin{array}{l}\text { Role Ambiguity } \\
\text { (RA) }\end{array}$} & RA1 & 0.819 & 2.792 & 0.0000 \\
\hline & RA2 & 0.840 & 2.344 & 0.0000 \\
\hline & RA3 & 0.751 & 2.427 & 0.0000 \\
\hline & RA4 & 0.917 & 2.354 & 0.0000 \\
\hline & RA6 & 0.868 & 2.542 & 0.0000 \\
\hline \multirow{7}{*}{$\begin{array}{l}\text { Role Conflict } \\
\quad \text { (RC) }\end{array}$} & $\mathrm{RC} 1$ & 0.791 & 3.635 & 0.0000 \\
\hline & $\mathrm{RC} 3$ & 0.663 & 2.917 & 0.0000 \\
\hline & $\mathrm{RC} 4$ & 0.703 & 3.021 & 0.0000 \\
\hline & $\mathrm{RC} 5$ & 0.690 & 3.094 & 0.0000 \\
\hline & RC6 & 0.862 & 3.031 & 0.0000 \\
\hline & RC7 & 0.720 & 2.875 & 0.0000 \\
\hline & $\mathrm{RC} 8$ & 0.798 & 3.042 & 0.0000 \\
\hline \multirow{4}{*}{$\begin{array}{l}\text { Work Stress } \\
\text { (WS) }\end{array}$} & WS5 & 0.783 & 3.042 & 0.0000 \\
\hline & WS6 & 0.581 & 2.375 & 0.0000 \\
\hline & WS7 & 0.798 & 3.302 & 0.0000 \\
\hline & WS8 & 0.814 & 2.812 & 0.0000 \\
\hline \multirow{7}{*}{$\begin{array}{l}\text { Quality of Audit Recommendation } \\
\text { (QAR) }\end{array}$} & QAR1 & 0.808 & 4.094 & 0.0000 \\
\hline & QAR 2 & 0.881 & 4.083 & 0.0000 \\
\hline & QAR 3 & 0.861 & 4.115 & 0.0000 \\
\hline & QAR 4 & 0.700 & 4.073 & 0.0000 \\
\hline & QAR 8 & 0.838 & 3.906 & 0.0000 \\
\hline & QAR 10 & 0.842 & 4.083 & 0.0000 \\
\hline & QAR 11 & 0.571 & 4.073 & 0.0000 \\
\hline
\end{tabular}

Based on Table 1, the first-factor Role Ambiguity has one item loaded less than the cut-off value (RA5), so this item is deleted. The second-factor Role Conflict has one factor less than the limit value (RC2), so this item is deleted. The four items removed from the third Factor Work Stress (WS1, WS2, WS3, and WS 4) had a factor loading below the cut off value, while the fourth Factor Quality of Audit Recommendations had four items removed (ARQ5, ARQ6, ARQ7, and ARQ 9) because they had factor loading below the cut off value.

Table 2

Construct Validity and Reliability

\begin{tabular}{|c|c|c|c|c|}
\hline & Composite Reliability & Cronbach's $\alpha$ & rhoA $^{\mathrm{a}}$ & AVE \\
\hline Role Ambiguity (RA) & 0.891 & 0.844 & 0.899 & 0.597 \\
\hline Role Conflict (RC) & 0.899 & 0.869 & 0.879 & 0.562 \\
\hline Work Stress (WS) & 0.835 & 0,734 & 0.756 & 0.562 \\
\hline Quality of Audit Recommendation (QAR) & 0.921 & 0,898 & 0.914 & 0.628 \\
\hline
\end{tabular}

Based on Table 2, shows that the composite reliability value of each variable shows a number $>0.7$ has high reliability. Average Variance Extracted value (AVE) $>0.5$ and Cronbach's alpha value $>0.6$ for all constructs. Based on these results, it can be concluded that all factors have met the standards of validity and reliability.

This paper applied these key factors to assess the inner model. They are as follows: (i) endogenous constructs' coefficient of determination (R2), (ii) effect size (f2), and (iii) path coefficients and their significance (significance levels, t-values, and $\mathrm{p}$ values). The results of the analysis are summarized in Table 3. 
Table 3

Testing research hypotheses

\begin{tabular}{|c|c|c|c|c|c|c|}
\hline $\boldsymbol{H}$ & Path & Path Coefficient & Effect Size $\left(f^{2}\right)$ & t-value & p-value & Conclusion \\
\hline 1 & $\mathrm{RC} \rightarrow \mathrm{QAR}$ & 0.336 & 0.009 & 2.552 & 0.016 & supported \\
\hline 2 & $\mathrm{RA} \rightarrow \mathrm{QAR}$ & -0.759 & 0.704 & 8.349 & 0.000 & supported \\
\hline 3 & $\mathrm{RC} \rightarrow \mathrm{WS}$ & 0.579 & 0.613 & 7.690 & 0.000 & supported \\
\hline 4 & $\mathrm{RA} \rightarrow \mathrm{WS}$ & 0.287 & 0.150 & 2.921 & 0.005 & supported \\
\hline 5 & $\mathrm{WS} \rightarrow \mathrm{QAR}$ & 0.008 & 0.000 & 0.054 & 0.957 & Rejected \\
\hline
\end{tabular}

$R^{2}$ Quality of Audit Recommendations/QAR=0.446

$R^{2}$ Work Stress/WS $=0,573$

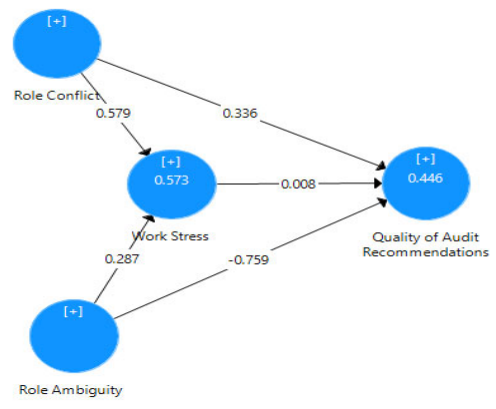

Model Estimation and Path Coefficient

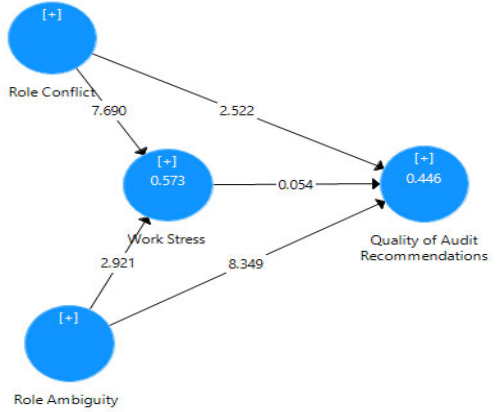

Model Significance test

Fig. 1. The results of testing the hypotheses

Based on Table 3 and Fig. 1, there is a significant direct effect between role ambiguity and role conflict on work stress and Quality of Audit Recommendation. It should be noted that if the significance values are greater than 1.96, the path significance of the relationships is confirmed. On this basis, hypotheses number 1, 2, 3, and 4 are confirmed and hypothesis number 5 is rejected. These results indicate that the role ambiguity and role conflict significantly affect the Quality of Audit Recommendation (r.446) and Work stress (r.573).

\subsection{The effects of role conflict and role ambiguity on quality of audit recommendations}

Hypothesis 1 was accepted as role conflict was significantly and positively related to Quality of audit recommendation $(.336, \mathrm{p}<.001)$. The results of the same study were also shown by Herlinawati (2012) and Widianingsih (2016) who analyzed the effect of the internal auditor's role stress on the quality of the internal auditor's recommendations, finding that role conflict affects the quality of audit recommendations. (Fisher, 1995; Fanani et al., 2008; Walton, 1987) states that role conflict can have a positive influence when the accepted role can give him new enthusiasm or energy or can be a source of inspiration and complement each other with his main task. The duties as an Internal Auditor can be in line with the main task as a lecturer, each audit case finding can become the real case which can be explained as material for discussion in class while maintaining the confidentiality of the audited. This shows that a lecturer who has two duties, as an Internal Auditor and carrying out the main task as a lecturer at a university does not cause the quality of audit recommendations when carrying out his duties but vice versa. Hypothesis 2 was accepted as role ambiguity was significantly and negatively related to the Quality of audit recommendation $(.-759, \mathrm{p}<.000)$. This can be triggered by complex conditions and changes in the internal auditor's operational environment, including complexity and changes in regulations and technology. The ambiguity of the role can create work tensions that potentially weaken the ability of internal auditors to maintain their commitment to professional independence and reduce the level of certainty whether the information obtained in the examination is objective and relevant (Ahmad. \& Taylor, 2009). The ambiguity of information related to the roles can lead to role ambiguity (Yung-Tai \& Chen-Hua, 2010). The studies by Al-Shbiel et al. (2018), Mohd Nor et al. (2015) result concerning minimized audit quality practices concentrated largely on the direct relationship between stress antecedents/stressors (role ambiguity and role conflict) and minimized audit quality practices.

\subsection{The effects of role conflict and role ambiguity on work stress}

The next test results related to the effect of role conflict and role ambiguity showed that there was a positive on work stress (H3 0.57 and H4.028 with $\mathrm{p}<.000$ ). This shows that additional tasks received with a fairly short completion time, long working hours and fatigue can have an impact on stress work (Jerusalem \& Chen, 2009; Greenhouses \& Beutell, 1985; Xu, 2009). Research results (Greenhouses et al., 1989; Xu, 2009; Soltania et al., 2013, Xu, 2009; Soltani et al., 2013) show that behavior-based conflict can occur when an individual's behavioral expectations playing two different roles are incompatible. Role ambiguity and role conflict were shown to be positively and strongly related to work stress (Ram et al., 2011). Role conflict and role ambiguity are among the antecedents of work stress which have been most cited in the research (Fisher $\&$ 
Gitelson, 1983). Role conflict, that is pressure to perform in two or more incompatible ways, has been tied conclusively to occupational stress in Western research whereas (Singh, 1991), lack of definitions or information regarding responsibilities, expectations and expected behaviors for a position or regarding its scope, can create role ambiguity. According to Ahmad and Taylor (2009) "role conflicts can derive from potential conflicting between their audit oversight role and the management consultative services role, as well as potential differences between directives of their professional body and demands of their organization's management.

\subsection{The effects of work stress on quality of audit recommendations}

The results of this study also indicate that the work stress does not affect the quality of audit recommendations either directly or indirectly (H5 .008 and p >.005). This result shows that the work stress experienced by the internal auditor in the internal control unit does not interfere with the audit recommendations. This can be explained through the role of a person's behavior who can complete work when he is in a condition where he can control emotions and work stress. Lecturers' tasks with complexities that are often faced, and their intellectual abilities greatly help them when receiving audit assignments with a short time limit so that work stress does not have an impact on the quality of audit recommendations (Cherniss, 2000). This is how the direct conflict between work demand and work control is created. Moreover, the more intense the conflict, the greater the work stress and its negative effects are likely to be, and the greater the negative consequences on the audit performance, the provision of sufficient evidence, and the efficiency of the audit judgment (Huanmin Yan. \& Xie, 2016).

\section{Conclusion}

This research finds that role conflict in universities has a positive effect on the quality of audit recommendation although the internal auditors have more than jobs with different tasks. This is because the tasks of both internal auditors and lecturers are complementary to each other. A lecturer has the intellectual ability to process the role he has so that both work objectives can be achieved and do not have an impact on reducing the quality of audit recommendations while serving as an internal auditor and vice versa the work of an auditor does not reduce the quality of teaching. Based on the analysis, the relationship between role ambiguity and Quality of audit recommendation shows have a negative significance. Each assigned task needs to be accompanied by sufficient and accurate information. If the information obtained is insufficient and inaccurate, the internal auditor cannot provide the quality of audit recommendation. Audit working papers and standard operating procedures are the main things in the internal auditor's work assignments so that if the internal auditor is not provided with information about the duties and work procedures, the internal auditor's performance will not be optimal in preparing audit recommendations. The current research exploring the role conflict and role ambiguity function as work stressors was confirmed in that the higher the experience of role conflict and/or role ambiguity, the higher the reported work stress. Based on the analysis it can be concluded that there is a significant direct effect between role ambiguity and role conflict on work stress. Marked by positive coefficient indicates that the high levels of role ambiguity and role conflict will lead to premature work stress among internal auditors. In addition, by revealing the relationship between stressors and work stress, internal audit managers and directors/Rectors should be aware of the work stress that is inherent in the nature of an internal auditor's work. In particular, to ensure that role conflict and role ambiguity do not have an impact on work stress, it is recommended that the Stakeholders/Rector need to consider the auditor's experience and intellectual ability in internal audit assignments and consider the completeness of information on each audit task to be carried out. It is also suggested that there is a need for regulations governing the division of internal auditors' work so that they are not in the teaching period.

Further research it is necessary to conduct testing by setting three categories of internal auditors at universities in Indonesia; Legal Entity Universities (PTBH), Public Service Entities (PT BLU), and Work Unit Universities (PT SATKER) as well as adding information technology support as a factor that can assist internal auditors in completing audit tasks and reducing work stress.

\section{References}

Ahmad, Z., \& Taylor, D. (2009). Commitment to independence by internal auditors: the effects of role ambiguity and role conflict. Managerial Auditing Journal, 24(9), 899-925.

Ahmad, Z., \& Taylor, d. D. (2009). Commitment to independence by Internal Auditors: The Effects of Role Ambiguity and Role Conflict. Managerial Auditing Journal, 24(9), 899-925.

Ahmad., Z., \& Taylor, D. (2009). Commitment to Independence by Internal Auditor: The Effects of Role Ambiguity and Role Conflict. Managerial Auditing Journal, 24, 899-925.

Ahmad., Z., \& Taylor, D. (2009). Commitment to Independence internal Auditor: The Effects of Role Ambiguity and Role Conflict. Managerial Auditing Journal, 24, 899-925.

Al-Khaddash, H., Nawas, R. A., \& Ramadan, A. (2013). Factors affecting the quality of Auditing: The Case of Jordanian Commercial Banks. International Journal of Business and Social Science, 4 (11), 206-222.

Al-Shbiel, S. O., Ahmad, M. A., Al-Shbail, A. M., Al-Mawali, H., \& Al-Shbail, M. O. (2018). The mediating role of work engagement in the relationship between organizational justice and junior accountants' turnover intentions. Academy of Accounting \& Financial Studies Journal., 22(1), 1-23.

Ariati K, K. (2014). Pengaruh Kompetensi Auditor Terhadap Kualitas Audit dengan Kecerdasan Spiritual Sebagai Variabel Moderating. Jurnal Ekonomika dan Bisnis., 3(3), 1.

Biddle. B.J. (1986, August). Recent Developments in Role Theory. Annual Review of Sociology, 12, 67-92. 
Bahtiar, E. (2019). Role Conflict, Role Ambiguity, Independence And Auditor Performance. Jurnal Akuntansi dan Keuangan, 1(2), 6577.

Baotha, S., \& Ussahawanitchakit, d. P. (2009). Audit Independence, Quality, and Credibility: Effects on Reputation and Sustainable Succes of CPAs in Thailand. International Journal of Business Research, 9(1), 1-25.

Baths, N. (1980). Job involvement and locus of control as moderators of role-perception/individual outcome relationships. Psychological Reports, 46, 111-119.

Beer, M., \& Walton, A. E. (1987). Organization change and development. Annual Review of Psychology., 38, 339-367.

Bhui, K., Dinos, S., Galant-Miecznikowska, M., de Jongh, B., \& Stansfeld, S. (2016). Perceptions of work stress causes and effective interventions in employees working in public, private and non-governmental organizations: a qualitative study. BJPsych Bulletin, 40(6), 318-325.

Cherniss., C. (2000). Emotional intelligence: What it is and why it matters. Consortium for Research on Emotional Intelligence in Organizations Emotional Intelligence 1.

Cooper, A. J., \& Robertson, I. a. (1998). Work Psychology: Understanding Human Behaviour in Workplace (3 ed.). London: PrenticeHall.

Dashti, M. S., \& Saedi, R. (2020). Investigating the Effects of Work and Social Stress Factors on Job Performance of Auditors. Journal of HealthAccounting, 9(1), 41-60.

Dowd, M. (2020, September 10). Negative Effects of a Heavy Workload. https://work.chron.com/theories-workrelated-stress15778.html.

Dukerich, J. M., \& Ashforth, B. E. (2001). Role Transitions in Organizational Life: An Identity-Based Perspective. The Academy Management Review, 26(4), 670.

Eby, L., Casper, W. L., C., A., \& Brinley, A. (2005). ). A retrospective on work-family research in IO/OB: A content analysis and review of the literature[Monograph]. Journal of Vocational Behavior, 124-197.

Fanani, Z., Hanif, R., \& Subroto, d. B. (2008). Pengaruh Struktur Audit, Konflik Peran dan Ketidakjelasan Peran terhadap Kinerja Auditor. Jurnal Akuntansi dan Keuangan Indonesia, 5(2), 139-155.

Fang, Y., \& Baba, V. (1993). Stress and turnover intention: A comparative study among nurses. International Journal of Comparative Sociology, 34, 24-38.

Fang, Y., \& Baba, V. (1993). Stress and turnover intention: A comparative study among nurses. International Journal of Comparative Sociology, 34, 24-38.

Fisher, C., \& Gitelson, R. (1983). A meta-analysis of role conflict and ambiguity. Journal of Applied Psychology, 68, 320 - 333.

Fisher, R. T. (2001). Role stress, the type A behavior pattern, and external auditor job satisfaction and performance. Behavioral Research in Accounting,, 13(1), 143-170.

Fisher., C., \& Gitelson, R. (1983). A meta-analysis of role conflict and ambiguity. Journal of Applied Psychology, 68, 320 - 333.

Fisher., R. (1995). Role Stress, The Type A Behaviour Pattern, And External Auditor Job Satisfaction And Performance. Lincoln University.

Flahrety, T., \& Dahlstrom, R. a. (1999). Organizational values and role stress as determinants of customer-oriented selling performance. Journal of Personal Selling and Sales Management, 19(2), 1-18.

Gerald, G. (2011). Role Conflict and the Teacher. Routledge, ISBN 978-0415689489., 3.

Gerber, L. M., \& Macionis, J. J. (2010). Sociology (7th ed.). Canadian: Pearson Canada.

Greenhouses, J., \& J.Beutell:, a. N. (1985). Source of Conflict Between Work and Family Roles. The Academy of Management Review, 10(1), 76-88.

Greenhouses, Parasuraman, J., S.Granrose, Robinowitz, C., \& Beutell, a. N. (1989). Sources of Work-Family Conflict among Two Carrier Couples. Journal of Vocational Behaviour, 133-1143.

Grzywacz, J. G. (2006). Quantifying work-family conflict among registered nurses. Research in nursing \& health, 29(5), 414-426.

Hafizuddin Islami, \& Sukarmanto, E. (2020). Effect of Role Conflict, Role Ambiguity, And Role Overload On Auditor Performance. Accounting Prociding, 6, pp. 608-611.

Hameed, A. (1995). Characteristics of internal auditing quality, field study in the Saudi Arabia. General managementJournal, 35(3), 405451.

Harris, E. G., Artis, A. B., Walters, J. H., \& Licata, J. W. (2006). (2006). Role stressors, service worker job resourcefulness, and job outcomes: An empirical analysis. Journal of Business Research, 59(4), 407-415.

Harrisons, B. (2005). Principles of International Medicine. . American: New York \& Sons. LTD.

Herlinawati. (2012). Pengaruh Tekanan Peran (Role Stress) Internal Auditor Terhadap Kualitas Rekomendasi Auditor Internal ( Studi survei pada PT PINDAD (Persero) Bandung ).

Hoseini, M. H., Asayesh, H., Amaniyan, S., Sharififard, F., Elahi, A., \& Kopaie., S. Y. (2021, February 15). Role conflict and role ambiguity as predictors of turnover intention among nurses. Retrieved from http://www.jnmsjournal.org IP: 36.78.36.251].

Huanmin Yan., \& Xie, S. (2016). How does auditors' work stress affect audit quality? Empirical evidence from the Chinese stock market. China Journal of Accounting Research, 9, 305-319.

Ivancevich, J. M. (2007). Human Resource Management. McGraw-Hill Irwin.

Ivancevich, J., Olekalns, M., \& Matteson., M. (2006). Human Resource Management (10 ed.). New York:: McGraw Hill, Inc..

Jachi, M., \& Yona, L. (2019). The Impact of Independence of Internal Audit Function on Transparency and Accountability Case of Zimbabwe Local Authorities. Research Journal of Finance and Accounting, 10(5), 64-77.

Jackson, S. a. (1985). A meta-analysis and conceptual critique of research on role ambiguity and role conflict in work settings. Organizational Behavior and Human Decision Processes, 36, 16-78.

Jerusalim.R, S., \& Chen.C, a. (2009). Work-Family Conflict and Career Development Theories: A Search for Helping Strategies. Journal of Counseling od Development, 492-500.

Johas, I. (n.d.). www.ibarakis.johas.go.jp/outline/magazine/attach/150803-2.pdf. Retrieved from The Brief Job.

Kahn, R., D.M, W., Quinn R, P., Snoek, J., \& R.A.Rosenthal. (2010). Organizational Stress: Studies in Role Conflict and Ambiguity. APA PSycNET.

Katz, D. a., \& Kahn, R. L. (1978). Katz, D., \& Kahn, R. L. (1978). The social psychology of organizations 2ed. John Wiley. (2 ed.). New York: John Wiley.

Katz, D. d., \& Kahn., R. L. (1987). The social psychology of organizations. New York: Wiley. 
Koo, C. M., \& Sim, H. S. (1999). On The Role Conflict of Auditors in Korea. Accounting, Auditing, and Accountability Journal, 12, 206219.

Larson, L. (2004). Internal auditors and job stress. Managerial Auditing Journal, 19(9), 1119-1130., 19(9), 1119-1130.

Lo'pez, D., \& Peters, G. (2012). The effect of workload compression on audit quality. . Auditing: J. Practice Theory, 31 (4), $139-165$.

Lu, L., Kao, S. F., Siu, O. L., \& Lu, C. Q. (2010). Work stressors, Chinese coping strategies, and job performance in Greater China. International Journal of Psychology, 45(4), 294-302.

Matthews, R. B.-F. (2010). Work social supports, role stressors, and work-family conflict: The moderating effect of age. Journal of Vocational Behavior, 76, 78-90.

Mohd Nor, M. N., Smith, M., Ismail, Z., \& Nahar, H. S. (2015). Unethical Audit Behaviour among Malaysian Auditors: An Exploratory Study. Pertanika Journal of Social Sciences \& Humanities., 23(Special Issue), 59-71.

Myaat, M. (2012, February 22). Retrieved 2012, from www.forbes.com/sites/mikemyatt.

Neu, D., Everett, J., \& Rahaman, A. S. (2013). Internal auditing and corruption within the government (the case of a Canadian sponsorship program. Contemporary Accounting Research, 30(3), 1223-1250.

Phillips, J., \& Andrews., L. (2014). Role Ambiguity, Role Conflict Or Burnout: Are These Areas Of Concern For Australian Palliative Care Volunteers? Pilot Study Results. The American journal of hospice \& palliative care, 1-18.

Ram, N., Khoso, I., Shah, A. A., Chandio, F. R., \& Shaikih., F. M. (2011, Februari). Role Conflict and Role Ambiguity as Factors in Work Stress among Managers: A Case Study of Manufacturing Sector in Pakistan. Asian Social Science, 7(2), 113-118.

Ram, N., Khoso., I., Shah, A. A., Chandio, F. R., \& Shaikih., M. (2011). Role Conflict and Role Ambiguity as Factors in Work Stress among Managers: A Case Study of Manufacturing Sector in Pakistan. Asian Social Science, 7(2), 113-118.

Rizzo, J., House, R., \& Lirtzman, d. S. (1970). Role Conflict and Ambiguity in Complex Organizations. Administrative Science Quarterly, $15(2), 150-163$.

Robkob, P., Sangboon, \& Leemanonwara, d. T. (2012). The Influence of Audit Independence, Audit Professionalism, and Audit Quality on Audit Value Creation: an Empirical Study of Tax auditors in Thailand. Review of Business Research, 12(1), 54-67.

Roussy, M. (2015). Welcome to the day-to-day of internal auditors: How do they cope with conflicts? Auditing A Journal of Practice \& Theory, 34 (2), 237-264.

Roussy, M., \& Brivot, M. (2016). Internal Audit Quality: a Polysemous notion? Accounting, Auditing and Accountability Journal, 29(5), 714-738.

Schuler, R. (1980). Definition and Conceptualization of Stress in Organizations. Organizational Behavior and Human Performance, 25, $184-215$.

Senatra. (1980). Role Conflict, Role Ambiguity, and Organizational Climate in a Public Accounting Firm. The Accounting Review, 55(4), 594-603.

SHBAIL, M. O. (2018). The Effect of Role Ambiguity and Role Conflict on Dysfunctional Audit Behaviour: Evidence from Jordan. International Journal of Academic Research in Accounting, Finance and Management Sciences, 8(3), 17-25.

Singh, J. \&. (1991). Boundary role ambiguity in marketing-oriented positions: A multidimensional, multifaceted operationalization. . Journal of Marketing Research, 328-338.

Soltania, I., Hajatpour, S., Khorram, J., \& Nejati, M. H. (2013). Investigating the effect of role conflict and role ambiguity on employees' job stress: Articulating the role of work-family conflict. Management Science Letters, 3, 1927-1936.

Soltania., I., Hajatpour., S., Khorramb, J., \& Nejatic, a. M. (2013). Investigating the effect of role conflict and role ambiguity on employees' job stress: Articulating the role of work-family conflict. Management Science Letters.

Stryker, S. \&., \& Burke, P. J. (2000). The past, present, and future of an identity theory. Social Psychology Quarterly, 63, $284-297$.

Sukirman, \& Sari, M. P. (2013). Model Deteksi Kecurangan Berbasis Fraud Triangle (Studi Kasus pada Perusahaan Publik di Indonesia. Jurnal Akuntansi \& Auditing., 9(2), 199-225.

T.Yung-Tai, \& Chen-Hua, d. C. (2010). Impact of role ambiguity and Role Conflict on Employee Creativity. African Journal of Business Management, 4(6), 869 - 882.

The Institute of Internal Auditors. (2019, January). Fraud and Internal Auditor Assurance Over Fraud Controls Fundamental to Success. (www.globaliia.org) Retrieved from https://na.theiia.org/about-ia/PublicDocuments/Fraud-and-Internal-Audit.pdf.

Truett.,C.(1979). Women in Educational Administration: Is There a Basic Role Conflict? Speeches Meeting Paper.

Walton, R. (1987). 'Managing conflict: Interpersonal dialogue and third-party roles'. Addison-Wesley.

Widianingsih, N. (2016). Pengaruh Profesionalisme Auditor Internal dan Role Stress terhadap Kualitias Rekomendasi Audit Internal (Studi pada PT Pos Indonesia Bandung). Bandung: http://repository.unpas.ac.id/id/eprint/9588.

Winoto, C. O., \& Harindahyani, S. (2020). The Effect of Auditor's Work Stress on Audit Quality of Listed Companies in Indonesia. Journal of Economics, Business, and Accountancy Ventura, 23 (3), 361 - 374.

Xu, C. (1999). Work stress system: mechanism, handling, and management. J. Zhejiang Normal Univ.: Social Sci, 5, 69-73.

Xu, L. (2009). View on Work-Family Linkage and Work-Family Conflict Model. International Journal of Business and Management, 229-233.

Zadegan, V. I., \& Aqa'i, M. A. (2018). Investigating the impact of auditors ' work stress on audit report quality in companies acquired in the Tehran stock exchange. Journal of Educational and Management Studies, 8(2), 31-40.

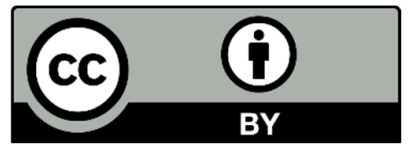

(C) 2022 by the authors; licensee Growing Science, Canada. This is an open access article distributed under the terms and conditions of the Creative Commons Attribution (CC-BY) license (http://creativecommons.org/licenses/by/4.0/). 